\title{
Correction to: Elevated expression of MKRN3 in squamous cell carcinoma of the head and neck and its clinical significance
}

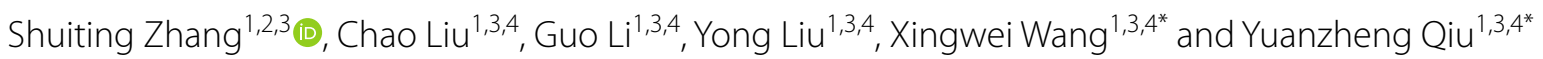

\section{Correction to: Cancer Cell Int (2021) 21:557 \\ https://doi.org/10.1186/s12935-021-02271-6}

In this article [1], the wrong figure appeared as Fig. 7a; the Fig. 7 should have appeared as shown below and the sentence needs to be revised in the "Functional analysis of the Result section" should be:

The sentence currently reads:

Further PPI analysis of MKRN3 illustrated that there were 31 nodes based on a combined score $\geq 0.7$ in the
STRING analysis, and that P53 might be a direct target gene of MKRN3 (Fig. 7a).

The sentence should read:

Further PPI analysis of MKRN3 illustrated that there were 31 nodes based on a combined score $\geq 0.15$ in the STRING analysis, and that P53 might be a direct target gene of MKRN3 (Fig. 7a).

*Correspondence: wang-xingwei@126.com; xyqyz@csu.edu.cn

1 Department of Otolaryngology Head and Neck Surgery, Xiangya

Hospital, Central South University, Changsha, Hunan, People's Republic of China

Full list of author information is available at the end of the article to the material. If material is not included in the article's Creative Commons licence and your intended use is not permitted by statutory regulation or exceeds the permitted use, you will need to obtain permission directly from the copyright holder. To view a copy of this licence, visit http://creativecommons.org/licenses/by/4.0/. The Creative Commons Public Domain Dedication waiver (http://creativecommons.org/publicdomain/zero/1.0/) applies to the data made available in this article, unless otherwise stated in a credit line to the data. 


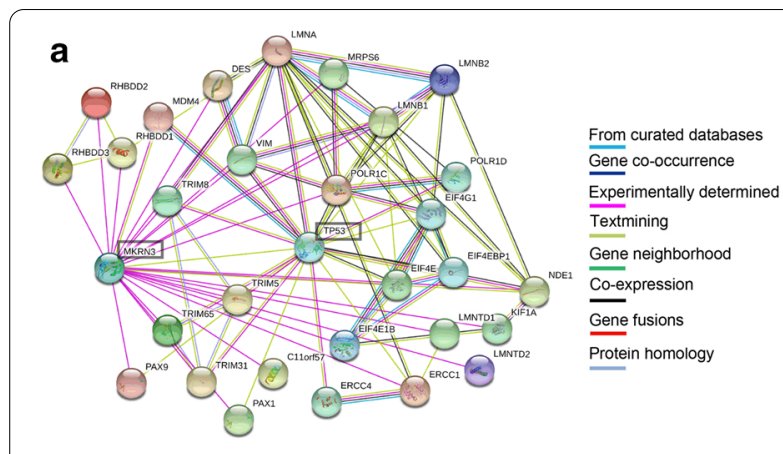

b

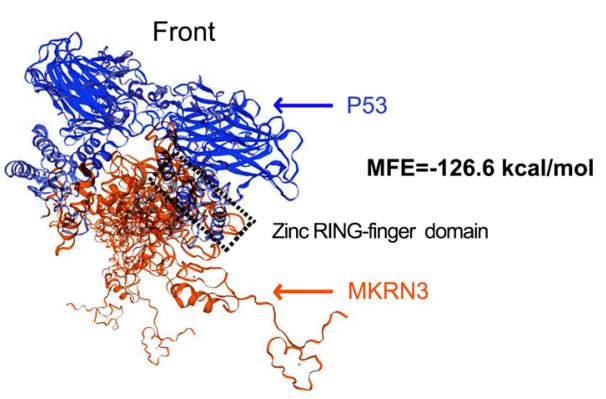

C

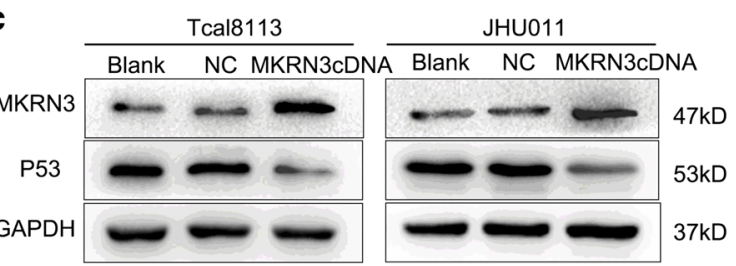

Fig. 7 P53 might be a target gene of MKRN3. a STRING analysis in the protein-protein interaction of MKRN3. Only the proteins with more than one interaction are displayed. $\mathbf{b}$ The homologous modeling and molecular docking with MKRN3 and P53. Red and blue cartoon represent MKRN3 and P53, respectively. The rectangle highlights the interacted domain. c Relative expression of P53 protein in Tcal1183 and JHU011 cells that transfected with MKRN3 CDNA and normalized for GAPDH

\section{Author details}

${ }^{1}$ Department of Otolaryngology Head and Neck Surgery, Xiangya Hospital, Central South University, Changsha, Hunan, People's Republic of China. ${ }^{2}$ Department of Anesthesiology, The Second Xiangya Hospital, Central South University, Changsha, Hunan, People's Republic of China. ${ }^{3}$ Otolaryngology Major Disease Research Key Laboratory of Hunan Province, Changsha, Hunan, People's Republic of China. ${ }^{4}$ Clinical Research Center for Pharyngolaryngeal Diseases, Voice Disorders in Hunan Province, Changsha, Hunan, People's Republic of China.

Accepted: 1 December 2021

Published online: 12 December 2021

\section{Reference}

1. Zhang S, Liu C, Li G, Liu Y, Wang X, Qiu Y. Elevated expression of MKRN3 in squamous cell carcinoma of the head and neck and its clinical significance. Cancer Cell Int. 2021;21:557. https://doi.org/10.1186/ s12935-021-02271-6.

\section{Publisher's Note}

Springer Nature remains neutral with regard to jurisdictional claims in published maps and institutional affiliations. 